ISSN 1678-3921

Journal homepage: www.embrapa.br/pab

For manuscript submission and journal contents, access: www.scielo.br/pab

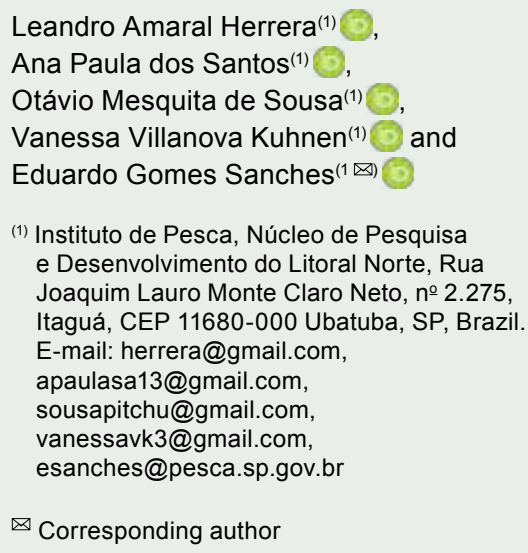

\section{Performance of common snook subjected to different feeding frequencies and rates using automatic feeders}

\begin{abstract}
The objective of this work was to evaluate the growth performance of common snook (Centropomus undecimalis) subjected to different feeding rates and frequencies using automatic feeders. Two experiments of 60 days each were carried out. In the first one, 20 fishes per tank were distributed in three feeding rates of: 5,10 , and $15 \%$ body weight per day. In the second experiment, 20 fishes per tank were distributed in nine tanks, in three feeding frequency: once a day, three times a day, and six times a day. Water parameters were maintained at the recommended level for the species. Final weight, body weight gain, specific growth rate, and feed conversion rate did not differ significantly between the 10 and $15 \%$ feeding rates. However, both rates differed from the $5 \%$ one. The feeding frequency of six times a day resulted in better values for final weight, final biomass, body weight gain, and specific growth rate. Therefore, common snook fingerlings should be fed at the feeding rate of $10 \%$ body weight per day, six times a day, in order to achieve the best growth performance.
\end{abstract}

Index terms: Centropomus undecimalis, automatic feeders, feeding management, mariculture, precision aquaculture, recirculation system.

\section{Desempenho do robalo-flecha submetido a diferentes frequências e taxas de alimentação em alimentadores automáticos}

\begin{abstract}
Resumo - O objetivo deste trabalho foi avaliar o desempenho do robaloflecha (Centropomus undecimalis) submetido a diferentes taxas e frequências alimentares com o uso de alimentadores automáticos. Dois experimentos, com duração de 60 dias cada um, foram realizados. No primeiro, 20 peixes por tanque foram distribuídos em três taxas alimentares de: 5,10 e $15 \%$ de peso vivo por dia. No segundo experimento, 20 peixes por tanque foram distribuídos em nove tanques e em três frequências alimentares de: uma vez, três vezes e seis vezes ao dia. Os parâmetros de qualidade da água foram mantidos dentro da faixa recomendada para a espécie. A massa final, o ganho de peso diário, a taxa de crescimento específico e a conversão alimentar não diferiram entre as taxas de alimentação de 10 e 15\%. Entretanto, ambas as taxas diferiram da de $5 \%$. A frequência de seis vezes ao dia resultou em maiores valores de massa final, biomassa final, taxa de crescimento específico e ganho de peso diário. Portanto, formas jovens de robalo-flecha devem ser alimentadas à taxa de $10 \%$ do peso vivo por dia, com frequência alimentar de seis vezes ao dia, para alcançar o melhor desempenho quanto à taxa de crescimento.
\end{abstract}

Termos para indexação: Centropomus undecimalis, alimentadores automáticos, manejo alimentar, maricultura, aquicultura de precisão, sistema de recirculação. 


\section{Introduction}

Common snook(Centropomus undecimalis) has been widely studied in marine and estuary areas. Besides the fish rusticity, and the decline of its stock in nature, its high-market value justify the interest in this species studies (García-Galano et al., 2003; Sanches et al., 2013; Passini et al., 2014). According to AlvarezLajonchère \& Taylor (2003), common snook is a gregarious species that can reach over $1 \mathrm{~m}$ long and $25 \mathrm{~kg}$ weigh, being therefore suited for recreational fishing. Considering that it is a euryhaline species, common snook can be produced in shrimp farms, in estuarine areas in Northeastern Brazil (Sanches et al., 2014b). Many studies have addressed the issues of reproduction and larviculture (Ferraz \& Cerqueira, 2010; Ibarra-Castro et al., 2011; Passini et al., 2014), enabling advances in the production of juveniles. However, little knowledge is available on feeding management practices, within recirculating seawater systems, where environmental variables influencing grow th can be controlled (Kodama et al., 2011; Sanches et al., 2014a).

A basic premise of a species cultivation is a feeding protocol aimed at: improving productive performance and survival; reducing feed conversion ratio and heterogeneity; and contributing to minimal food waste (Aydin et al., 2011; Al Zahrani et al., 2013). However, information are still scarce as to the amount of feed that can lead to excess, causing deterioration of water quality, increasing the amount of wastewater released to the environment, and lowering environmental sustainability of the cultivation (Kasiri et al., 2011).

Both feeding rate and frequency should be considered for a better expression of zootechnical performance of fish. However, these parameters can vary according to the species, age, and water temperature (Rosenlund et al., 2004). Some studies have reported that a higher-feeding frequency can improve fish productive performance. Zhou et al. (2003) tested five feeding frequencies $(2,3,4,12,24$ meals a day) in juveniles of Carassius auratus gibelio, and concluded that the optimal feeding frequency for the species is 24 meals a day. Sousa et al. (2012) also observed good results in using higher frequencies, and concluded that increasing the number of meals improves feed distribution, reduces competition for food, and provides a greater batch uniformity and fish weight. Cunha et al. (2013) assessed the effect of feeding rates and feeding frequencies on the growth of pompano (Trachinotus marginatus), and concluded that $8 \%$ rate (live weight), offered in eight meals, improved the productive performance. Higher-feeding rates led to higher-food conversion efficiency, whereas lower rates affected growth negatively.

Higher-feeding frequencies can worsen food conversion, and deteriorate water quality, reducing the profitability of the activity (Booth et al., 2008). Both low- and high-feeding frequencies could result in growth retardation, poor feed efficiency, decreased intestinal enzyme activities, and low IGF-I expression in blunt snout bream juvenile Megalobrama amblycephala (Tian et al., 2015). Therefore, the proper use of feeding regimes is an efficient way to reduce costs and improve fish growth (Lee \& Pham, 2010; Lawrence et al., 2012). Feeding frequency may also play a role in mediating aggression and cannibalism (Manley et al., 2015; Ribeiro et al., 2015).

Besides being scarce, studies on the growth of common snooks - both in experiments and commercial production - report only feeding frequencies from once to twice a day (Tsuzuki \& Berestinas, 2008; Ramos et al., 2012; Sanches et al., 2014a; Moreira et al., 2015). Even scarcer are studies that address the use of automatic feeders for tropical marine fish farming. Automatic feeders allow of feed supply to be delivered at regular quantities and intervals, resulting in a greater accuracy and efficiency in its distribution, specially with greater number of meals.

The objective of this work was to evaluate the growth performance of common snook subjected to different feeding rates and frequencies using automatic feeders.

\section{Materials and Methods}

Two experiments were sequentially carried out with captive-bred juveniles of common snook. In the first one, 20 fish $(1.71 \pm 0.18 \mathrm{~g}$, and $5.9 \pm 0.2 \mathrm{~cm}$ total length) per tank were randomly distributed in treatments of three feeding rates, with three replicates: 5, 10, and $15 \%$ body weight per day. The second experiment also used 20 fish $(1.19 \pm 0.47 \mathrm{~g}$ and $4.7 \pm 0.8 \mathrm{~cm}$ total length) per tank, which were randomly distributed in three feeding frequencies, with three replicates: once a day, three times a day, and six times a day.

A commercial feed was offered with centesimal composition made by the manufacturer with: $41.8 \%$ 
crude protein, $8.75 \%$ ether extract, $6.77 \%$ ash, and $1.96 \%$ crude fiber. Feed particle size had 1-2 mm diameter. Each tank received an automatic feeder unit (Soma Ltda., Sun Sun, Xangai, China) with $50 \mathrm{~g}$ storage capacity. In the feeding rate experiment, fishes were fed three times a day (at 9:00, 12:00, and 17:00 h). In the feeding frequency experiment, feed was offered at $10 \%$ body weight per day. The total feed offered was measured weekly during the refilling of the automatic feeders.

Each experiment was performed in nine $150 \mathrm{~L}$ circular tanks, in a salt-water recirculation system equipped with mechanical filtration, a skimmer, and water sterilization by UV lights. The circulation rate of the tanks was $200 \%$ (total water volume of the tanks was renewed twice a day). Before entering the system, all fish were kept in a freshwater bath for 5 min (Kerber et al., 2011) to eliminate ectoparasites. Evaporative losses from the system were restored daily with deionized water. After the last feeding of the day, tank bottoms were cleaned by siphoning, in order to remove solid waste. Out of the total volume of the recirculation system $10 \%$ was replaced weekly, to eliminate components that were not retained, or eliminated, by the filtering system.

Each experiment lasted 60 days. Feed consumption (measured by the mass difference between feed supplied and leftovers at the end of feeding), and mortality rate were verified daily. In order to obtain the biometric data, fish of all treatments were anesthetized with benzocaine $\left(0.05 \mathrm{~g} \mathrm{~L}^{-1}\right)$, measured by an ictiometer, and weighed individually on a digital electronic scale ( $0.01 \mathrm{~g}$ precision), at the beginning of the trial period, and every 20 days until its end. Total length $(\mathrm{cm})$, mass (g), and feed intake (g per day), as well as mortality rate, were calculated using the following performance parameters: survival (S, \%); specific growth rate, SGR $(\%$ body weight per day $)=100 \times\left(\ln \mathrm{W}_{2}-\ln \mathrm{W}_{1}\right) \Delta \mathrm{t}^{-1}$, in which $\mathrm{W}_{2}$ is the average final weight, $\mathrm{W}_{1}$ is the average initial weight, and $\Delta t$ is the rearing period (days); body weight gain, BWG (g per day) $=\left(\mathrm{W}_{2}-\mathrm{W}_{1}\right) \Delta \mathrm{t}^{-1}$; and feed conversion ratio, $F C R=C_{f} / D_{f}$, in which $C_{f}$ is the total amount of food consumed during the period, and $\mathrm{D}_{\mathrm{f}}$ is the weight gain during the experimental period. It should be noted that the final weight of each individual fish and final biomass - the final weight of the whole fish lot of each treatment - were used to evaluate the individual performance of fish and the support capacity of the system, respectively.

Temperature and dissolved oxygen in the water were monitored with the oximeter YSI 51 (Yellow Springs Instrument Company, Yellow Springs, OH, USA). Total ammonia was monitored by the colorimetric method with a Tetratest kit (Tetra Werke, Melle, Germany), and salinity, with an optical refractometer F3000 (Bernauer Aquaculture, Blumenau, Brazil). Oxidationreduction potential and $\mathrm{pH}$ and were measured with ph/ORP Controller (PH-303) (Omega Engineering Inc., Taiwan). All parameters were measured daily in the sump linking the water outlet of the tanks.

The experiments were carried out in a completely randomized design, with three replicates. Parameters evaluated were subjected to the analysis of variance, and the means were compared by Tuckey's test, at $5 \%$ probability. The values expressed as survival percentage were transformed according to $\operatorname{arcsen}(\mathrm{x})^{0.5}$.

\section{Results and Discussion}

Common snook was sensitive to the different feeding rates evaluated (Table 1). The lowest feeding rate $(5 \%)$ resulted in the lowest specific growth rate and weight gain, as well as in highest feed conversion rate. In parallel, the highest feeding frequency resulted in the highest specific growth rate and weight gain, as well as in the lowest feed conversion rate.

The treatments did not influence the survival rates, which were considered high and showed the rusticity of common snook reared in salt-water recirculation systems. The use of a recirculation system with highwater flow through the filtering system favored the maintenance of water quality. Values of temperature, dissolved oxygen, total ammonia, and salinity (Table 2) remained within the levels considered ideal for the cultivation of $C$. undecimalis, as reported by Ferraz \& Cerqueira (2010), providing suitable conditions for fish to express their growth potential. The temperature of the water recirculation system was kept at $28^{\circ} \mathrm{C}$. This temperature provides a better productive performance for other species of Centropomidae, as reported for fat snook Centropomus parallelus (Oliveira et al., 2013).

Another variable that can influence feeding rate and frequency is the fish density in tanks. Higher densities should prevent dominance hierarchy to occur, which would improve feed consumption by dominated fish 
(Başçinar et al., 2007). Studies on common snook showed that the densities used did not allow of the expression of dominance hierarchies, enabling all fish to have access to adequate feed amounts.

In general, high-feeding rates would implicate inefficiency of the digestive metabolism and impairment of water quality, whereas low-feeding rates would increase competition for food, as well as a high-batch heterogeneity, resulting in low growth. Al Zahrani et al. (2013) studied the feeding rate for $2.1 \mathrm{~g}$ juveniles of Asian grouper Epinephelus polyphekadion, and observed that the specific growth rate was higher in treatments that used higher feed rates. In the present study, common snook showed no significant differences for final weight, weight gain, specific growth rate, and feed conversion at 10 to $15 \%$ rates; however, both differed at 5\% rate (Table 1).

Specific growth rate, feed conversion, and feeding rate interacted significantly. As the feeding rate increased, the specific growth rate rose to a certain point, and then began to decline (Figure 1). The opposite was observed for feeding conversion ratio, which decreased until feeding rate of $10 \%$ was reached, and increased subsequently. These observations corroborate the results from Luo et al. (2006), in an experiment with $10 \mathrm{~g}$ Asian groupers Epinephelus coioides fed different feeding rates. The authors observed significant changes in the performance, in which higher rates were more effective for increasing the specific growth rate that varied from 0.06 to 1.44 . Feed conversion rate ranged from 1.31 to 3.08 , and it was more efficient at intermediate rates. Cunha et al. (2013) evaluated the effect of different feeding rates
$(4,8,12,16$, and $20 \%$ body weight per day) on the individual performance of $4.8 \mathrm{~g}$ juvenile pompano [Trachinotus marginatus (Cuvier, 1832)]. The authors concluded that lowest rate $(4 \%)$ provided the worst growth and increased the aggressive behavior of fish. Moreover, a 4\% feeding rate was not suitable for fish to meet their basic energy needs, and to express their growth potential, and the $8 \%$ feeding rate was the most suitable for this species. Opposite to these results, Barbosa et al. (2011) observed that feed conversion reduced when feeding rates were increased for fat snook. The authors concluded that the low-food conversion of fish fed $6 \%$ body weight per day was caused by feed leftovers, probably because feeding was above the intake capacity and satiety of juveniles of such species, as leftovers were not observed in the tanks that received 3\% body weight per day. Our results evidenced the importance of establishing a feeding rate suitable for the fish weight range evaluated, in order to allow of a greaterperformance efficiency due to lower-feed conversion.

Most studies used low-feeding frequencies, and feed was supplied manually, ranging from one to four meals a day (García-Galano et al., 2003; Canton et al., 2007; Tsuzuki \& Berestinas, 2008). The use of automatic feeders enhances the possibility of fractioning the feed supply, which allows of the offering of feed at regular intervals throughout the day, and allows of a reduced interference of the handler in the process (Zhou et al., 2003; Sousa et al., 2012). Farmed fish are usually fed once or twice a day, due to workforce costs (Sanches et al., 2014b). Currently, food handling to young common snook

Table 1. Mean \pm standard deviation of productive performance parameters of common snook (Centropomus undecimalis) subjected to different feeding rates and feeding frequecies ${ }^{(1)}$.

\begin{tabular}{|c|c|c|c|c|c|c|}
\hline \multirow[t]{2}{*}{ Parameter } & \multicolumn{3}{|c|}{ Feeding rate (body weight per day) } & \multicolumn{3}{|c|}{ Feeding frequency } \\
\hline & $5 \%$ & $10 \%$ & $15 \%$ & Once a day & Three times a day & Six times a day \\
\hline Final length $(\mathrm{cm})$ & $6.9 \pm 0.9 b$ & $7.6 \pm 0.9 \mathrm{a}$ & $7.7 \pm 1.1 \mathrm{a}$ & $5.5 \pm 0.7 \mathrm{~b}$ & $5.7 \pm 0.9 \mathrm{~b}$ & $6.2 \pm 1.0 \mathrm{a}$ \\
\hline Final weight (g) & $2.81 \pm 0.87 b$ & $3.43 \pm 1.22 \mathrm{a}$ & $3.55 \pm 1.51 \mathrm{a}$ & $1.43 \pm 0.52 b$ & $1.71 \pm 0.77 \mathrm{~b}$ & $2.11 \pm 0.93 \mathrm{a}$ \\
\hline Final biomass (g) & $47.71 \pm 4.07 \mathrm{~b}$ & $61.79 \pm 1.05 \mathrm{a}$ & $60.39 \pm 8.38 \mathrm{a}$ & $26.75 \pm 2.72 b$ & $31.84 \pm 9.39 \mathrm{~b}$ & $40.13 \pm 6.46 \mathrm{a}$ \\
\hline Survival (\%) & $85.0 \pm 8.7$ & $90.0 \pm 0.0$ & $85.0 \pm 5.0$ & $93.3 \pm 7.6$ & $93.3 \pm 5.8$ & $95.0 \pm 0.0$ \\
\hline SGR (\% body weight per day) & $0.83 \pm 0.06 \mathrm{~b}$ & $1.16 \pm 0.10 \mathrm{a}$ & $1.22 \pm 0.13 \mathrm{a}$ & $0.31 \pm 0.03 \mathrm{c}$ & $0.60 \pm 0.08 \mathrm{~b}$ & $0.95 \pm 0.11 \mathrm{a}$ \\
\hline Body weight gain (g per day) & $0.018 \pm 0.004 \mathrm{~b}$ & $0.029 \pm 0.007 \mathrm{a}$ & $0.031 \pm 0.008 \mathrm{a}$ & $0.004 \pm 0.001 \mathrm{~b}$ & $0.009 \pm 0.003 b$ & $0.015 \pm 0.006 \mathrm{a}$ \\
\hline Feed conversion rate & $1.5 \pm 0.1 \mathrm{a}$ & $1.1 \pm 0.1 \mathrm{~b}$ & $1.2 \pm 0.1 \mathrm{~b}$ & $1.1 \pm 0.1 \mathrm{~b}$ & $1.2 \pm 0.1 \mathrm{~b}$ & $1.5 \pm 0.1 \mathrm{a}$ \\
\hline
\end{tabular}

(1)Means followed by equal letters in the row, for feeding rate or feeding frequency, do not differ by Tukey's test, at 5\% probability. SGR, specific growth rate. Final weight (FW) is the FW of each fish. Final biomass is the FW of the whole fish lot of each treatment. 
consists of providing feed twice or three times a day (Tsuzuki \& Berestinas, 2008). Attempts to increase the feeding frequency face significantly higher costs of workforce (Lawrence et al., 2012). Feeding mechanization can be an alternative in this respect, since the use of automatic feeders allows of higherfeeding frequencies, without aggregating labor costs (Sousa et al., 2012).

Many studies, however, did not obtain significant differences between the feeding frequencies evaluated, probably because feeding rates were not strictly established, and feed was offered by hand until apparent satiety of fish, which is a subjective

Table 2. Variables of water quality during the experimental period of 60 days.

\begin{tabular}{lc}
\hline Variable & Mean $\pm \mathrm{SD}$ \\
\hline Temperature $\left({ }^{\circ} \mathrm{C}\right)$ & $27.6 \pm 0.8$ \\
Salinity & $31.5 \pm 2.7$ \\
Dissolved oxygen $\left(\mathrm{g} \mathrm{L}^{-1}\right)$ & $6.8 \pm 0.7$ \\
Saturation $(\%)$ & $99.2 \pm 1.3$ \\
Total ammonia $\left(\mathrm{mg} \mathrm{L}^{-1}\right)$ & $0.1 \pm 0.1$ \\
$\mathrm{pH}$ & $8.1 \pm 0.5$ \\
Oxidation-reduction potential $\left(\mu \mathrm{S} \mathrm{cm}^{-1}\right)$ & $268.5 \pm 9.1$ \\
\hline
\end{tabular}

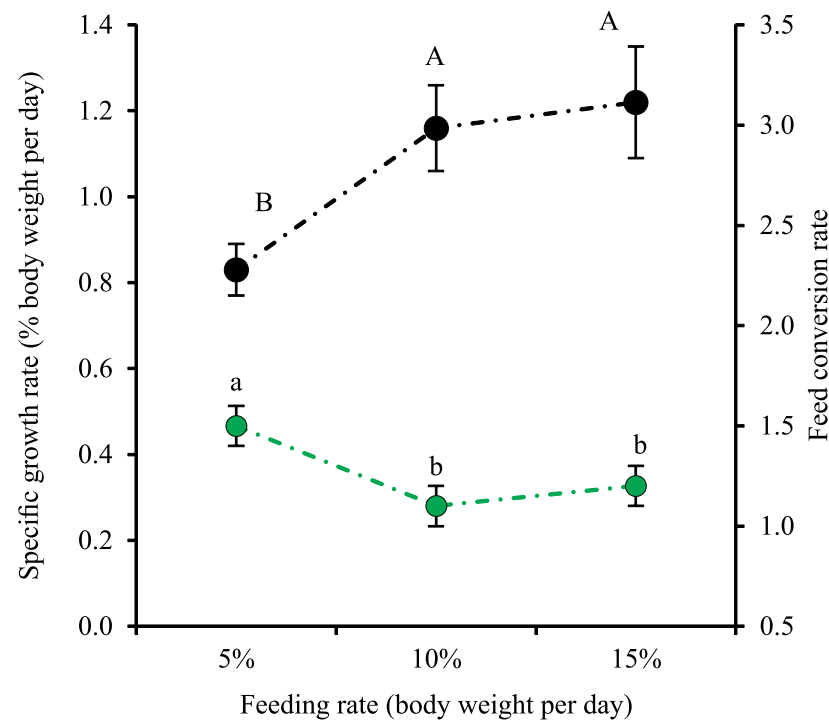

Figure 1. Specific growth rate (black dots) and feed conversion rates (green dots) as influenced by feeding rates for common snook (Centropomus undecimalis). Means followed by equal letters do not differ by Tukey's test, at $5 \%$ probability. parameter determined by the keeper (García-Galano et al., 2003; Başçinar et al., 2007; Aydin et al., 2011). More recently, Sousa et al. (2012), using automatic feeders and a feeding rate at $7 \%$ body weight per day, proved that increased feed frequencies implicate greaterweight gain, reduction of fish variation coefficient, and reduction of feed conversion rate. The optimal feeding rate for common snook, observed by Sousa et al. (2012), was $10 \%$ of body weight per day.

Our results showed that a feeding frequency of six times a day was more suitable than the other analyzed frequencies, in optimizing the productive performance of common snook (Figure 2). This frequency led to higher values of final weight, final biomass, specific growth rate, and weight gain. Studies conducted with other fish species have shown that food consumption and weight gain increase with higher-feeding frequencies (Başçinar et al., 2007; Kasiri et al., 2011). Zhou et al. (2003) evaluated five feeding frequencies (2, 3, 4, 12, and 24 times per day), for goldfish, Carassius auratus gibelio, and reported better results of productive performance at the frequency of 24 times a day. Cho et al. (2003), working with Plecoglossus altivelis, provided feed ad libitum at six feeding frequencies (once every 2 days, and 1, 2, 3, 4,

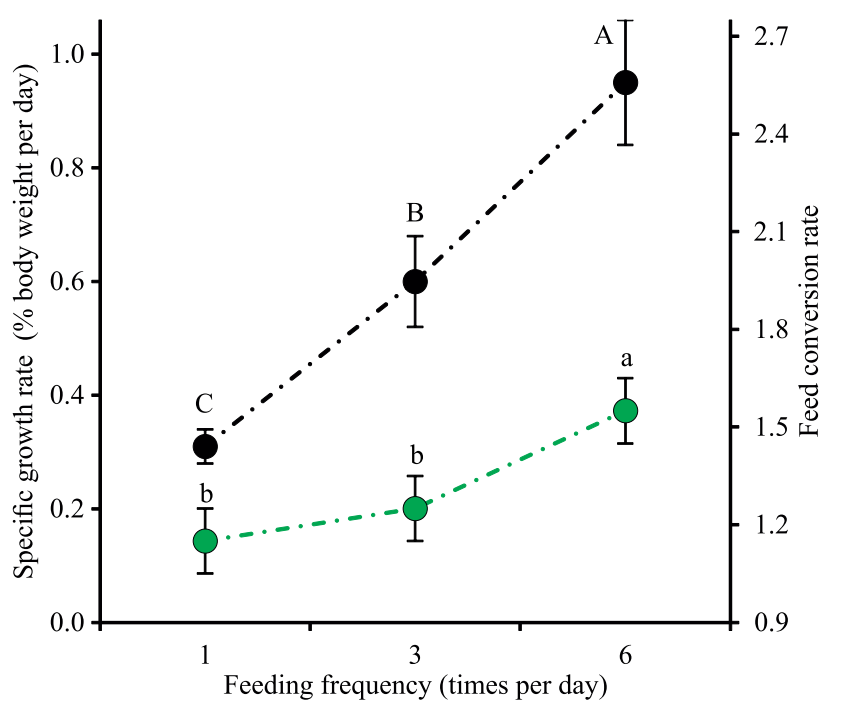

Figure 2. Specific growth (black dots) and feed conversion rates (green dots) as influenced by feeding frequencies for common snook (Centropomus undecimalis). Means followed by equal letters do not differ by Tukey's test, at $5 \%$ probability. 
and 6 times a day) and, similarly to the present work, greater-weight gains were obtained at higher-feeding frequencies. Canton et al. (2007) studied feeding frequencies (1, 2, 3, and 4 times a day) with Rhamdia quelen $(7.47 \mathrm{~g})$, and observed that fish fed four times a day gained almost twice as much weight, and showed higher-specific growth rate than those fed only once a day.

Lower-feeding frequencies can restrict consumption of the total food supplied due to the capacity of the digestive tract, causing low-productive performance (Marques et al., 2008). Therefore, high-feeding frequencies can provide greater benefits. Sousa et al. (2012) evaluated the use of automatic feeders at high-feeding frequencies (12 and 24 times a day) for Nile tilapia Oreochromis niloticus. According to the authors, the 24-times-a-day frequency resulted in greater-weight gain and in the saving of more than $360 \mathrm{~kg}$ feed, for each ton of fish produced. This represented an effective reduction of production costs and a significant reduction in the release of effluents.

Specific growth and feed conversion rates were directly augmented with the increased feeding frequencies. These results concur with those obtained by Başçinar et al. (2007), who observed that the lower the frequency, the better the feed conversion; and that the higher the feeding frequency, the better the fish growth. No references were found whether this relationship would continue, if frequencies were significantly increased (over 12 times a day).

Higher-feeding frequencies for common snook resulted in worse results of feed conversion. Several studies have shown that higher-feeding frequencies result in the worsening of food conversion (Jeong et al., 2003; Kasiri et al., 2011; Cunha et al., 2013). Sousa et al. (2012), however, showed that an exceedingly high-food frequency (24 times a day) might result in reduced feed conversion. Conversely, García-Galano et al. (2003) concluded that at lower-feeding frequencies $(1,2$, and 3 times a day), the feed conversion was not affected. These authors used feeding until apparent satiety, instead of a fixed feeding frequency, which may have influenced the results of feed conversion. It is worth noting, however, that food consumption at this stage is very small because of fish low weight (28.9 $\mathrm{g}$ in common snook) and, therefore, it may be more interesting to obtain a rapid growth, even with higher feed conversion rates.
Some species can benefit from the reduction of feeding frequency due to their physiological and metabolic characteristics. Thia-Eng \& Seng-Keh (1978) showed that a decreased feeding frequency favored the growth of the Asian grouper, Epinephelus tauvina, which obtained the most efficient result when feed was supplied once every other day. For the Atlantic codfish Gadus morhua, no differences were found to weight gain and feed conversion, when fish were subjected to once-a-day and once-every-otherday feeding frequencies (Rosenlund et al., 2004). Similar results were obtained for $4.1 \mathrm{~g}$ common snook juveniles by Tsuzuki \& Berestinas (2008), who did not observe significant differences for weight gain, specific growth rate (0.9 to 1.3 ), and feed conversion (1.3 to 1.6) due to feeding frequencies (once and twice a day). Growth performance of juvenile cobia, cultured in near-shore cages, can be optimized with twice-aday feeding frequency, which would also facilitate husbandry procedures and minimize costs related to labor and vessel utilization (Moreira et al., 2015). In all these studies, fish were fed until apparent satiety. Corrêa et al. (2010) observed that feeding frequencies $(1,2$, and 4 times a day) did not influence fat snook weight gain, specific growth rate (1.3 to 1.6), and feed conversion (4.8 to 5.9), in fresh water. These results are possibly related to the fact that the feeding rate at $6 \%$ body weight a day was adopted, which is considered very low for fish in this weight range $(0.6 \mathrm{~g})$. In contrast to these studies, we observed that the use of a higherfeeding frequency ( 6 times a day) provided the best results for common snook.

It is important to highlight that many studies distribute the feeding frequencies within a very narrow period (from 8:00 to 17:00, for instance), leaving a significant portion of the day without food supply, which could hinder fish performance. However, Henken et al. (1985) showed that consumption of large food amounts, in short intervals of time, lessens the digestive efficiency.

Feeding management involves an intense use of workforce, leading to high costs of fish production. Besides, it implies a limitation of supply related to the size of the production units and workforce, which restricts the adoption of higher-feeding frequencies. Therefore, the adoption of automatic feeders, could optimize the use of workforce and enable the implementation of higher-feeding frequencies, which 
can promote the productive performance of fish, with a greater efficiency of feed supply and lesser effluent discharge to the environment.

\section{Conclusion}

The feeding rate of $10 \%$ body weight per day, at a feeding frequency of six times a day, promotes the best productive performance of common snook juveniles.

\section{Acknowledgments}

To Fundação de Amparo à Pesquisa do Estado de São Paulo (Fapesp), for financial support (process number 2014/07886-7); and to Eber G. Cretton for English text review.

\section{References}

AL ZAHRANI, A.W.; MOHAMED, A.H.; SERRANO JR, A.E.; TRAIFALGAR, R.F.M. Effects of feeding rate and frequency on growth and feed utilization efficiency in the camouflage grouper (Epinephelus polyphekadion) fingerlings fed a commercial diet. European Journal of Experimental Biology, v.3, p.596-601, 2013.

ALVAREZ-LAJONCHÈRE, L.; TAYLOR, R.G. Economies of scale for juvenile production of common snook (Centropomus undecimalis Bloch). Aquaculture Economics \& Management, v.7, p.273-292, 2003. DOI: https://doi.org/10.1080/13657300309380345.

AYDIN, I.; KÜÇÜK, E.; ŞAHIN, T.; KOLOTOĞLU, L. The effect of feeding frequency and feeding rate on growth performance of juvenile black sea turbot (Psetta maxima, Linneaus, 1758). Journal of Fisheries Sciences, v.5, p.35-42, 2011.

BARBOSA, M.C.; NEVES, F. de F.; CERQUEIRA, V.R. Taxa alimentar no desempenho de juvenis de robalo-peva em tanquerede. Acta Scientiarum. Animal Sciences, v.33, p.369-372, 2011. DOI: http://doi.org/10.4025/actascianimsci.v33i4.11413.

BAŞÇINAR, N.; ÇAKMAK, E.; ÇAVDAR, Y.; AKSUNGUR, $\mathrm{N}$. The effect of feeding frequency on growth performance and feed conversion rate of black sea trout (Salmo trutta labrax Pallas, 1811). Turkish Journal of Fisheries and Aquatic Sciences, v.7, p.13-17, 2007.

BOOTH, M.A.; TUCKER, B.J.; ALLAN, G.L.; FIELDER, D.S. Effect of feeding regime and fish size on weight gain, feed intake and gastric evacuation in juvenile Australian snapper Pagrus auratus. Aquaculture, v.282, p.104-110, 2008. DOI: https://doi.org/10.1016/j.aquaculture.2008.06.027.

CANTON, R.; WEINGARTNER, M.; FRACALOSSI, D.M.; ZANIBONI FILHO, E. Influência da freqüência alimentar no desempenho de juvenis de jundiá. Revista Brasileira de Zootecnia, v.36, p.749-753, 2007. DOI: https://doi.org/10.1590/ S1516-35982007000400001.
CHO, S.H.; LIM, Y.S.; LEE, J.H.; LEE, J.K.; PARK, S.; LEE, S.M. Effects of feeding rate and feeding frequency on survival, growth, and body composition of Ayu post-larvae Plecoglossus altivelis. Journal of the World Aquaculture Society, v.34, p.8591, 2003. DOI: https://doi.org/10.1111/j.1749-7345.2003.tb00042.x.

CORRÊA, C.F.; LEONARDO, A.F.G.; TACHIBANA, L.; CORREAA JUNIOR, L. Frequência alimentar para juvenis de robalo-peva criados em água doce. Revista Acadêmica: Ciências Agrárias e Ambientais, v.8, p.429-436, 2010.

CUNHA, V.L. da; SHEI, M.R.P.; OKAMOTO, M.H.; RODRIGUES, R.V.; SAMPAIO, L.A. Feeding rate and frequency on juvenile pompano growth. Pesquisa Agropecuária Brasileira, v.48, p.950-954, 2013. DOI: https://doi.org/10.1590/ S0100-204X2013000800020.

FERRAZ, E. de M.; CERQUEIRA, V.R. Influência da temperatura na maturação gonadal de machos de robalo-flecha, Centropomus undecimalis. Boletim do Instituto de Pesca, v.36, p.73-83, 2010.

GARCÍA-GALANO, T.; PÉREZ ， J.C.; GAXIOLA， G.; SÁNCHEZ, A. Effect of feeding frequency on food intake, gastric evacuation and growth in juvenile snook, Centropomus undecimalis (Bloch). Revista de Investigaciones Marinas, v.24, p.145-154, 2003.

HENKEN, A.M.; KLEINGELD, D.W.; TIJSSEN, P.A. T. The effect or feeding level on apparent digestibility of dietary dry mater, crude protein and gross energy in the African catfish Clarias gariepinus (Burchell, 1822). Aquaculture, v.51, p.1-11, 1985. DOI: https://doi.org/10.1016/0044-8486(85)90235-2.

IBARRA-CASTRO, L.; ALVAREZ-LAJONCHÈRE， L.; ROSAS, C.; PALOMINO-ALBARRÁN, I.G.; HOLT, G.J.; SANCHEZ-ZAMORA, A. GnRHa-induced spawning with natural fertilization and pilot-scale juvenile mass production of common snook, Centropomus undecimalis (Bloch, 1792). Aquaculture, v.319, p.479-483, 2011. DOI: https://doi.org/10.1016/j.aquaculture.2011.07.014.

JEONG, D.-S.; KAYANO, Y.; ODA, T.; NAKAGAWA, H. Influence of feeding regime on fatty acid composition in young red-spotted grouper Epinephelus akaara. Fisheries Science, v.69, p.569-574, 2003.

KASIRI, M.; FARAHI, A.; SUDAGAR, M. Effects of feeding frequency on growth performance and survival rate of angel fish, Pterophyllum scalare (Perciformes: Cichlidae). Veterinary Research Forum, v.2, p.97-102, 2011.

KERBER, C.E.; SANCHES, E.G.; SANTIAGO, M.; LUQUE, J.L. First record of Neobenedenia melleni (Monogenea: Capsalidae) in sea-farmed cobia (Rachycentron canadum) in Brazil. Revista Brasileira de Parasitologia Veterinária, v.20, p.331-333, 2011. DOI: https://doi.org/10.1590/S1984-29612011000400013.

KODAMA, G.; ANNUNCIAÇÃO, W.F.; SANCHES, E.G.; GOMES, C.H. de A.M.; TSUZUKI, M.Y. Viabilidade econômica do cultivo do peixe palhaço, Amphiprion ocellaris, em sistema de recirculação. Boletim do Instituto de Pesca, v.37, p.61-72, 2011.

LAWRENCE, C.; BEST, J.; JAMES, A.; MALONEY, K. The effects of feeding frequency on growth and reproduction in zebrafish (Danio rerio). Aquaculture, v.368-369, p.103-108, 2012. DOI: https://doi.org/10.1016/j.aquaculture.2012.09.022. 
LEE, S.-M.; PHAM, M.A. Effects of feeding frequency and feed type on the growth, feed utilization and body composition of juvenile olive flounder, Paralichthys olivaceus. Aquaculture Research, v.41, p.e166-e171, 2010. DOI: https://doi.org/101111/ j.1365-2109.2010.02491.x.

LUO, Z.; LIU, Y.-J.; MAI, K.-S.; TIAN, L.-X.; TAN, X.-Y.; SHI, J.F. Effects of feeding levels on growth performance, feed utilization, body composition, and apparent digestibility coefficients of nutrients for grouper Epinephelus coioides juveniles. Journal of the World Aquaculture Society, v.37, p.32-40, 2006. DOI: https://doi.org/10.1111/j.1749-7345.2006.00004.x.

MANLEY, C.B.; RAKOCINSKI, C.F.; LEE, P.G.; BLAYLOCK, R.B. Feeding frequency mediates aggression and cannibalism in larval hatchery-reared spotted seatrout, Cynoscion nebulosus. Aquaculture, v.437, p.155-160, 2015. DOI: https://doi.org/10.1016/j.aquaculture.2014.11.012.

MARQUES, N.R.; HAYASHI, C.; GALDIOLI, E.M.; SOARES, T.; FERNANDES, C.E.B. Freqüência de alimentação diária para alevinos de carpa-capim (Ctenopharyngodon idella, V.). Boletim do Instituto de Pesca, v.34, p.311-317, 2008.

MOREIRA, C.B.; ROMBENSO, A.N.; CANDIOTTO, F.B.; TSUZUKI, M.Y. Feeding frequency affects growth of juvenile cobia Rachycentron canadum cultured in near-shore cages. Boletim do Instituto de Pesca, v.41, p.219-226, 2015.

OLIVEIRA, L.A.A.G.; ALMEIDA, A.M.; PANDOLFO, P.S.V.; SOUZA, R.M. de; FERNANDES, L.F.L.; GOMES, L.C. Crescimento e produtividade de juvenis de robalo-peva a diferentes temperaturas e taxas de alimentação. Pesquisa Agropecuária Brasileira, v.48, p.857-862, 2013. DOI: https://doi.org/10.1590/S0100-204X2013000800007.

PASSINI, G.; CARVALHO, C.V.A.; STERZELECKI, F.C.; CERQUEIRA, V.R. Induction of sex inversion in common snook (Centropomus undecimalis) males, using 17- $\beta$ oestradiol implants. Aquaculture Research, v.47, p.1090-1099, 2014. DOI: https://doi.org/10.1111/are.12565.

RAMOS, F.M.; SANCHES, E.G.; FUJIMOTO, R.Y.; COTTENS, K.F.; CERQUEIRA, V.R. Crescimento de juvenis da garoupaverdadeira Epinephelus marginatus submetidos a diferentes dietas. Boletim do Instituto de Pesca, v.38, p.81-88, 2012.

RIBEIRO, F.F.; FORSYTHE, S.; QIN, J.G. Dynamics of intracohort cannibalism and size heterogeneity in juvenile barramundi Lates calcarifer at different stocking densities and feeding frequencies. Aquaculture, v.444, p.55-61, 2015. DOI: https://doi.org/10.1016/j.aquaculture.2015.03.029.
ROSENLUND, G.; KARLSEN, Ø.; TVEIT, K.; MANGORJENSEN, A.; HEMRE, G.-I. Effect of feed composition and feeding frequency on growth, feed utilization and nutrient retention in juvenile Atlantic cod, Gadus morhua L. Aquaculture Nutrition, v.10, p.371-378, 2004. DOI: https://doi.org/10.1111/ j.1365-2095.2004.00312.x.

SANCHES, E.G.; MELLO, G.L. de; AMARAL JUNIOR, H. Primeira ocorrência de malformação na coluna vertebral em juvenis de robalo-flecha. Boletim do Instituto de Pesca, v.39, p.77-83, 2013.

SANCHES, E.G.; SILVA, F. da C.; LEITE, J.R.; SILVA, P.K.A.; KERBER, C.E.; SANTOS, P.A. dos. A incorporação de óleo de peixe na dieta pode melhorar o desempenho da garoupaverdadeira Epinephelus marginatus? Boletim do Instituto de Pesca, v.40, p.147-155, 2014a.

SANCHES, E.G.; SILVA, F. daC.; RAMOS, A.P.F.D'A. Viabilidade econômica do cultivo do robalo-flecha em empreendimentos de carcinicultura no Nordeste do Brasil. Boletim do Instituto de Pesca, v.40, p.577-588, 2014b.

SOUSA, R.M.R.; AGOSTINHO, C.A.; OLIVEIRA, F.A.; ARGENTIM, D.; NOVELLI, P.K.; AGOSTINHO, S.M.M. Productive performance of Nile tilapia (Oreochromis niloticus) fed at different frequencies and periods with automatic dispenser. Arquivo Brasileiro de Medicina Veterinária e Zootecnia, v.64, p.192-197, 2012. DOI: https://doi.org/10.1590/S010209352012000100027.

THIA-ENG, C.; SENG-KEH, T. Effects of feeding frequency on the growth of young estuary grouper, Epinephelus tauvina (Forskål), cultured in floating net-cages. Aquaculture, v.14, p.3147, 1978. DOI: https://doi.org/10.1016/0044-8486(78)90138-2.

TIAN, H.-Y.; ZHANG, D.-D.; LI, X-F.; ZHANG, C.-N.; QIAN, Y.; LIU, W.-B. Optimum feeding frequency of juvenile blunt snout bream Megalobrama amblycephala. Aquaculture, v.437, p.6066, 2015. DOI: https://doi.org/10.1016j.aquaculture.2014.11.032.

TSUZUKI, M.Y.; BERESTINAS, A.C. Desempenho de juvenis de robalo-peva Centropomus parallelus com diferentes dietas comerciais e freqüências alimentares. Boletim do Instituto de Pesca, v.34, p.535-541, 2008.

ZHOU, Z.; CUI, Y.; XIE, S.; ZHU, X.; LEI, W.; XUE, M.; YANG, $Y$. Effect of feeding frequency on growth, feed utilization, and size variation of juvenile gibel carp (Carassius auratus gibelio). Journal of Applied Ichthyology, v.19, p.244-249, 2003. DOI: https://doi.org/10.1046/j.1439-0426.2003.00453.x. 